\title{
THE IMPACT OF GENDER ON JEWISH RELIGIOUS THOUGHT. EXEMPLAR: JEWISH FEMINIST THEOLOGY
}

\author{
Melissa Raphael *
}

\begin{abstract}
Jewish feminists have been criticizing and reformulating their tradition's theological language, concepts and ethics since the 1970s. With principal reference to the work of Judith Plaskow, Rachel Adler, Tamar Ross, and Melissa Raphael, this article outlines some key aspects of the Jewish feminist theological project. The article goes on to suggest that while Orthodox Jewish feminism might attend more closely to a revision of the gendered theology that informs its halakhic observance, the prophetic momentum of liberal Jewish feminist theology might be greater were it to profess a more personalist, realist account of the exercise of the divine redemptive will in history.
\end{abstract}

\section{The initial prophetic critique}

From the early 1970s a small number of Jewish women began to express theological concerns about the kind of language, concepts and values used to evoke the character of God. Judith Plaskow, who had identified as a feminist since 1969, was equipped by both feminist theory and her postgraduate studies in Protestant theology to argue that the Jewish tradition's assumption of women's Otherness to men and to God is theological and determines their socio-cultural roles and status in Judaism before any particular halakhot might do.' Judith Ochshorn also pointed out that the masculine God's Oneness relegates anything that is not the same, namely the feminine, to a lesser or deviant order of power and reality. ${ }^{2}$ Where the divine and human masculine will is considered normative and ordains the nature and sphere of female activity as the silent object of its discourse, women are dehumanized. They are the Jews "who are not there" as Rachel Adler had described them in 1973. In 1979, the Jewish feminist novelist and critic Cynthia Ozick famously pointed out that while the whole point of the Torah is to countermand the ways of the world, its ethic has not extended to proscription of the dehumanization of women. This glaring omission led Ozick to propose an 11th commandment: "Thou shalt not lessen the humanity of women."

Plaskow's recognition (after de Beauvoir) of the problem of feminine alterity was shared with Christian feminists. So too was her conviction that any theistic tradition should be considered idolatrous if it makes the masculine body the primary bearer of the divine image of a God who can only be imagined in male modes and language. ${ }^{5}$ Other concerns were more particular to Jewish feminist theology. Not least among these was the observation that the biblical record of women having been kept at a distance from the site of revelation on Sinai, where Moses addressed only male Israelites who were physically set apart from women beforehand, was a mandate for the exclusion of women from the whole history and process of halakhah. Thenceforth women, whose actual covenantal inclusion in the narrative had been left in some doubt, would be spoken on behalf of by rabbis for whom they all too often constituted mere anomalies or problems to the maintenance of the given order. While Biale, Hauptman, Wegner, Baskin and others' pioneering feminist studies of women in rabbinic literature had demonstrated that rabbinic deliberation on matters concerning women is often paternalistically benign, the ideological construction

\footnotetext{
* Professor of Jewish Theology, University of Gloucestershire and Leo Baeck College, London, UK. Email: mraphael@glos.ac.uk

'Judith Plaskow, "The Right Question is Theological," in Susannah Heschel, ed., On Being a Jewish Feminist: A Reader (New York: Schocken Books, 1983), 223-33.

${ }^{2}$ Judith Ochshorn, The Female Experience and the Nature of the Divine (Bloomington: Indiana University Press, 1981).

${ }^{3}$ Rachel Adler, "The Jew Who Wasn't There: Halakhah and the Jewish Woman," in Heschel ed., On Being a Jewish Feminist, $12-18$.

"Cynthia Ozick, "Notes Towards Finding the Right Question," in Heschel, ed., On Being a Jewish Feminist, 120-51, 146-50.

${ }^{5}$ Judith Plaskow, Standing Again at Sinai:Judaism from a Feminist Perspective (New York: Harper San Francisco, 1991), 147-8.
} 
of women as an innately separate class of people (BT Shabbat 62a) had nonetheless left them prey to misogynistic distrust or idealization, the one being the obverse of the other.

By the early 1980s, Susannah Heschel had asked, "If the Talmud is the product of a particular time and particular individuals, what religious authority does it hold, and why should we return to it after discovering teachings and rulings within it that limit and oppress us? ${ }^{96}$ Ten years later, Plaskow was still asking why anyone would want to figure their relationship with God in terms of a hierarchical, controlling model that they would not countenance in any of their other relationships: "why should the experience of God as a dominant hierarch be liberating or holy?" If God is no less morally accountable than humanity, why should Jews accept the authority of halakhah as divine revelation if such is either mediated or constituted by, or otherwise compromised by, the patriarchal nature of its own model of God?

The dilemma was a stark one. Nonetheless, by definition, a feminist Jew is one who has concluded that the tradition does in fact countermand its own patriarchy, and over the course of nearly forty years there were a number of increasingly nuanced attempts to circumvent, if not resolve, some of these critical questions. A postmodern climate encouraged narratival strategies, most notably in Rachel Adler's 1998 Engendering Judaism, which emphasized how the polyphonic, sometimes playful, dimensions of rabbinic texts were conducive to feminist theological counter-reading. ${ }^{8}$ Or in my feminist theology of the Holocaust, published in 2003, the figure of the Shekhinah was used to suggest counterpatriarchal, but nonetheless quite traditional, notions of divine pathos and presence to suffering. ${ }^{9}$ With the emergence of Queer theology, which shaped Plaskow's growing interest in sexual theology, the work of Dan Boyarin and, by the early twenty-first century, that of younger scholars such as Emily Silverman, there was an increasing recognition of the need for Jewish theology to be recast not just in the light of (Ashkenazi) women's histories and experiences, but of all those who, spiritually as well as genitally, do not fit neatly into categories such as male and female, or even gay and straight.

\section{Cross-denominational social engagements with the tradition}

Contemporary Jewish feminist religious thought, including that of Modern Orthodox feminists, continues to be conditioned by its origins in a liberal tradition that attempts to moderate the centres of self-appointed and self-aggrandizing power. All Jewish feminism is the product of a characteristically modern moment in which equal rights and opportunities are secured through a process of social emancipation predicated on the free, rational assent of the whole community to natural or meritorious, rather than essential or caste authority. I think Molly Farneth is right that what Rachel Adler, Judith Plaskow and Tamar Ross have in common is their postliberal theological emphasis on the sociality of reason and revelation. ${ }^{10}$ Like other forms of postliberal theology, Jewish feminist theology accepts the binding authority of halakhah only in so far as it is conducive to the flourishing of relationships and social practices in which it is interpreted and applied. I will suggest that its primarily social perspective is Jewish feminist theology's weakness (or its strength - depending on your point of view).

In 2004 the Modern Orthodox theologian Tamar Ross asserted, with her more liberal sisters, that Jewish women's liberation consists in the fact that "no truth has the power simply to bang us over the head"." The boundaries between the human and divine word are fluid and dynamic. God's will is heard not only through the rabbinic interpretation of scripture, but also through the historical warrant of the people's consensual acceptance of that interpretation. Despite Ross's denominational differences

\footnotetext{
${ }^{6}$ Heschel, "Introduction," On Being a Jewish Feminist, xxi.

"Judith Plaskow, "What's Wrong with Hierarchy?" (1992) in The Coming of Lilith: Essays on Feminism, Judaism, and Sexual Ethics, 1972-2003. (Boston: Beacon Press, 2005), 128-142, particularly 141.

${ }^{8}$ Rachel Adler, Engendering Judaism: An Inclusive Theology and Ethics (Boston: Beacon Press, 1998).

${ }^{9}$ Melissa Raphael, The Female Face of God in Auschwitz: A Jewish Feminist Theology of the Holocaust (London and New York: Routledge, 2003).

${ }^{10}$ Molly Farneth, "Feminist Jewish Thought as Postliberal Theology," Modern Theology 33 (2017): 31-46.

"Tamar Ross, Expanding the Palace of Torah: Orthodoxy and Feminism (Boston: Brandeis University Press, 2004), 218.
} 
with Plaskow and Adler, ${ }^{12}$ she shares their view that the validity of a tradition is related to the social context from which it derives its meaning: it is not hermetically sealed from change. Influenced by cumulative elements in Maimonides and Rav Kook's theology of revelation, Ross' notion of an openended progressive revelation entails that feminism, too, is a God-given means for revealing God's will and developing human sensibilities. ('These and these are the words of the Living God', as God pronounced to settle an argument between Hillel and Shammai.) Patriarchy is not divinely ordained forever but can be divinely superseded. Women must therefore be included in the process of halakhic deliberation. If they are not, the Jewish people will fail to hear God's ongoing revelation.

Plaskow and Adler share Ross' social account of revelation even if their rejection of nonreciprocal structures of domination and subordination is more pronounced. The authority of halakhah, Adler suggests, perhaps with greater clarity than Plaskow, is located neither in its divine origin nor in any universal and timeless truth of its precepts, but rather in its capacity to imagine a better, more worldcreating, less world-maintaining, community. ${ }^{13}$

\section{Weighing the achievements of Jewish feminist religious thought}

As I have observed elsewhere, " the (quite properly Jewish) tendency of progressive Jewish feminist religious thought to focus on the social, immanent effects of revelation rather than confessionally on their transcendent cause, has led to a certain paucity of constructive realist claims about God. (It seems not uncoincidental that while parts of my own feminist theology of the Holocaust, The Female Face of God in Auschwitz [2003] predicated on the real, active presence of God in history, have been anthologized, its argument appears to have had far more impact on Christian thought than Jewish. $)^{15}$

My point is supported by Norman Solomon who has recently observed that by the second half of the twentieth century modern Jewish religious thinkers were no longer conceiving of God in the classic terms of one who intervenes righteously, lovingly and providentially in a human history whose outcomes are measurable in terms of some form of reward or punishment. Still less, he added, do Jewish feminists adhere to such a model of God, which they find tyrannically masculinist. ${ }^{16}$

This theological reticence may owe something to Jewish feminist theology's immediate origins in 1960's countercultural, anti-authoritarian politics, the feminist version of whose ethos aimed to create communities that would validate each woman's life choices and lend them spiritual meaning. The Jewish tributary of the women's liberation movement produced undoubted gains. In liberal Jewish communities, Cynthia Ozick's $11^{\text {th }}$ commandment became more or less redundant. But while the gendered Other was no longer dehumanized, God may have been de-divinized. A liberationist approach - combined with a traditional Jewish distrust of Christian theology's doctrinal approach to attaining knowledge of God - may have left liberal Jewish feminism's theism somewhat adrift. The modern theological trajectory of Plaskow's work exemplifies just such an attenuation of God as Solomon describes. Having long been convinced that God is no more unambiguously good as God is

\footnotetext{
${ }^{12}$ See further, Judith Plaskow, "The View from Here: Gender Theory and Gendered Realities. An Exchange between Tamar Ross and Judith Plaskow," Nashim 13 (Spring, 2007): 207-51.

${ }^{13}$ Adler, EngenderingJudaism, 34-6.

${ }^{14}$ Melissa Raphael, "Standing at a Demythologised Sinai?: Reading Jewish Feminist Theology Through the Critical Lens of Radical Orthodoxy” in Rosemary Ruether and Marion Grau, eds., Interpreting the Postmodern: Responses to 'Radical Orthodoxy,' (New York and London: T.\&T. Clark, 2006), 197-214; Melissa Raphael, "Feminist Theology and the Jewish Tradition," in Mary McClintock Fulkerson and Sheila Briggs, ed., The Oxford Handbook of Feminist Theology (New York: Oxford University Press, 2012,) 51-72; Melissa Raphael, Religion, Feminism and Idoloclasm: Being and Becoming in the Women's Liberation Movement (Abingdon and New York: Routledge, 2019), 184-205.

${ }^{15}$ See e.g. Steven Katz, ed., Wrestling with God:Jewish Theological Responses During and After the Holocaust (New York: Oxford University Press, 2007), 649-62; Holocaust Studies: A Journal of Culture and History 15 (2011), (an issue of the journal presenting a set of articles on The Female Face of God in Auschwitz).

${ }^{16}$ Norman Solomon, "The Attenuation of God in Modern Jewish Thought," Melilah 12 (2015): Atheism, Scepticism and Challenges to Monotheism, 97-109.
} 
unambiguously gendered, ${ }^{17}$ by 2016 , with a tremendous sense of relief at no longer having to struggle to believe in a good and omnipotent God, she has come to regard any personalist theology as no more than wishful thinking. She now argues for a God who has been de-gendered altogether as the creative energy or Ground of Being that, for no extrinsic moral or historical purpose, sustains all life. ${ }^{8}$

It is questionable whether the God Plaskow now proposes, towards the close of her career, offers a sufficiently Jewish, warm and purposive model of God to satisfy most people in most congregations, even liberal ones. The biblical God is, after all, personal; the obligatory nature of Jewish life probably makes most sense as a product of divine love, intelligence and intentionality. The postulation of a non-personal God may make it difficult to hang on to the idea that humanity - not least girls and women - are uniquely made in the image of God. Crucially, for me (and I am not Orthodox) Plaskow's theology weakens, if not vanquishes, the Jewish hope of a historically interruptive messianic order of unprecedented peace and the restoration of original goodness or natural harmony.

I'd like to turn briefly now to the ways in which Modern Orthodox feminism's reluctance to do more than implicit theology (the depth of Tamar Ross' engagement with the process of revelation is something of an exception) may also undermine its sustainability. Recent times have proved the truth of Blu Greenberg's famous contention that where there is a rabbinic will there is a halakhic way. Rachel Biale's 1984 characterization of women as "silent recipients, outsiders to the [halakhic] process" ${ }^{\text {"19 }}$ no longer rings true in any but the most closed of Haredi communities. Contemporary Modern Orthodox women have unprecedented opportunities for advanced Torah study that qualifies them to take on increasingly extensive roles as, say, halakhic advisors advocating for women in marital matters and as spiritual leaders, if mainly of other women, as the heads of midrashot.

Yet the fault-line in Orthodox feminist religious thought remains much as it was when Plaskow first identified it in $1982 .^{20}$ That is, while Orthodox women increasingly enjoy access to essentially masculine ritual and pedagogic environments it is on condition of their fulfilment of traditional roles within nuclear families in communities whose poskim only superficially, if at all, address or remedy the implications of the absence of other gendered perspectives or subjectivities. Orthodox feminists' tendency to at once protest specific exclusions and ignore their broader conceptual source, does little to alter the fundamental scheme in which both women and LGBTQI people are subject to the law but cannot become the authoritative agents of its formulation, interpretation and application because the default mode and character of the commanding God as "He" remains more or less unchallenged.

To conclude, there is now extensive recognition that halakhah is thoroughly embedded in aggadah or theology; that without theology's conceptualisation and narration of God's relationship to the world no one would have any idea why there is a halakhah or why one might be obligated to it in the first place. ${ }^{21}$ Cynthia Ozick's contention that halakhah, not theology, is the engine of reform is outdated. On the one hand, this means that without Orthodox Jewish feminists devoting more explicit attention to the nature of the God in whose will the mitzvot originate, and without the rabbinical academy becoming better-educated in the comprehensive paradigm shift feminism demands, ${ }^{22}$ the advances they have won will yield not much more than a set of ameliorations, leaving their canon intact. On the other hand, without progressive feminists devoting more attention to the real exercise of the divine will in history

\footnotetext{
${ }^{17}$ See e.g. Judith Plaskow, "Facing the Ambiguity of God" (1991), in The Coming of Lilith, 134-7; Goddess and God in the World: Conversations in Embodied Theology, 2017 (Minneapolis: Fortress Press, 2016), 127-30; See also Manchester Centre for Jewish Studies Sherman Lectures 2000: http:/www.manchesterjewishstudies.org/sherman-lectures-2000/. And Judith Plaskow, "The Challenge of Transgender to Compulsory Heterosexuality," in Marvin E. Ellinson and Judith Plaskow, eds, Heterosexuality in Contemporary World Religions: Problems and Prospects (Cleveland: Pilgrim Press, 2007), 34. Also Hava Tirosh Samuelson and Aaron W. Hughes, eds, Judith Plaskow: Feminism, Theology and Justice (Leiden: Brill, 2014), 45-68.

${ }^{18}$ Carol Christ and Judith Plaskow, Goddess and God in the World, (Minneapolis: Fortress Press, 2016), esp. 184-7, 234-50.

${ }^{19}$ Rachel Biale, Women and Jewish Law (New York: Schocken Books, 1984), 8.

${ }^{20}$ Judith Plaskow, "The Right Question is Theological," in Heschel, ed., On Being a Jewish Feminist, 223-33.

${ }^{21}$ See e.g. Neil Gilman, Traces of God: Seeing God in Torah, History and Everyday Life (Woodstock: Jewish Lights, 2006 ), 114.

${ }^{22}$ See Deidre Butler, “Modern Jewish Thought and Jewish Feminist Thought: An Uncommon Conversation,” Religion Compass 6 (2012): 51-71.
} 
there will be an ever more diluted prophetic basis for the work of redemption in general and the revalorization of women's lives as subjects and agents of the tradition in particular.

But on a more celebratory summary note, the manifold achievements of the last four or five decades of Jewish feminist religious thought must not be underestimated. The practical advances of Modern Orthodox feminism are considerable and, in some quarters of the movement, its account of tradition as a cumulative revelation has led to female rabbinical ordination and may eventually lead to dayanic certification. With its egalitarian Reform head-start, liberal Jewish feminist theology, and the Queer theology for which it laid the foundations, has sought the liberation of Jewish women, LGBTQI people, and above all, that ultimate Other: God, from the tyranny of their patriarchal idea. As such, together, the varieties of Jewish feminist thought surely constitute the most radically and systemically emancipatory moment of Jewish modernity.

\section{BIBLIOGRAPHY}

Adler, Rachel. “The Jew Who Wasn't There: Halakhah and the Jewish Woman,” in Susannah Heschel, ed., On Being a Jewish Feminist, 12-18. New York: Schocken, 1995.

Adler, Rachel. Engendering.Judaism: An Inclusive Theology and Ethics. Boston: Beacon Press, 1998.

Biale, Rachel. Women and Jewish Law. New York: Schocken Books, 1984.

Butler, Deidre. "Modern Jewish Thought and Jewish Feminist Thought: An Uncommon Conversation." Religion Compass 6 (2012): 51-71.

Christ, Carol and Judith Plaskow. Goddess and God in the World: Conversations in Embodied Theology. Minneapolis: Fortress Press, 2016.

Farneth, Molly. "Feminist Jewish Thought as Postliberal Theology." Modern Theology 33 (2017): 3146.

Gilman, Neil. Traces of God: Seeing God in Torah, History and Everyday Life. Woodstock: Jewish Lights, 2006.

Katz, Steven, ed. Wrestling with God:Jewish Theological Responses During and After the Holocaust. New York: Oxford University Press, 2007.

Ochshorn, Judith. The Female Experience and the Nature of the Divine. Bloomington: Indiana University Press, 1981.

Ozick, Cynthia. "Notes Towards Finding the Right Question," in Susannah Heschel, ed., On Being a Jewish Feminist, 120-51. New York: Schocken, 1995.

Plaskow, Judith. "The Right Question is Theological," in Susannah Heschel, ed., On Being a Jewish Feminist: A Reader. New York: Schocken Books, 1983.

Plaskow, Judith. Standing Again at Sinai:Judaism from a Feminist Perspective. New York: Harper San Francisco, 1991.

Plaskow, Judith. "Facing the Ambiguity of God" (1991). In The Coming of Lilith: Essays on Feminism, Judaism and Sexual Ethics, 1972-2003, 134-7. Boston: Beacon Press, 2005.

Plaskow, Judith. "What's Wrong with Hierarchy?" (1992) in The Coming of Lilith: Essays on Feminism, Judaism, and Sexual Ethics, 1972-2003, 128-42. Boston: Beacon Press, 2005.

Plaskow, Judith. "The Challenge of Transgender to Compulsory Heterosexuality," in Marvin E. Ellinson and Judith Plaskow, eds., Heterosexuality in Contemporary World Religions: Problems and Prospects. Cleveland: Pilgrim Press, 2007.

Plaskow, Judith. "The View from Here: Gender Theory and Gendered Realities. An Exchange between Tamar Ross and Judith Plaskow.” Nashim 13 (Spring, 2007): 207-251.

Raphael, Melissa. The Female Face of God in Auschwitz: AJewish Feminist Theology of the Holocaust. London and New York: Routledge, 2003.

Raphael, Melissa. "Standing at a Demythologised Sinai?: Reading Jewish Feminist Theology Through the Critical Lens of Radical Orthodoxy," in Rosemary Ruether and Marion Grau, eds., 
Interpreting the Postmodern: Responses to 'Radical Orthodoxy,'197-214. New York and London: T. \& T. Clark, 2006.

Raphael, Melissa. "Feminist Theology and the Jewish Tradition," in Mary McClintock Fulkerson and Sheila Briggs, eds., The Oxford Handbook of Feminist Theology, 51-72. New York: Oxford University Press, 2012.

Raphael, Melissa. Religion, Feminism and Idoloclasm: Being and Becoming in the Women's Liberation Movement. Abingdon and New York: Routledge, 2019.

Ross, Tamar. Expanding the Palace of Torah: Orthodoxy and Feminism. Boston: Brandeis University Press, 2004.

Solomon, Norman. "The Attenuation of God in Modern Jewish Thought." Melilah 12 (2015): Atheism, Scepticism and Challenges to Monotheism: 97-109.

Tirosh-Samuelson, Hava and Aaron W. Hughes, eds. Judith Plaskow: Feminism, Theology and Justice. Leiden: Brill, 2014. 